\title{
Why does critical literacy hit a snag in the Iranian EFL setting?
}

\section{¿Por qué la alfabetización crítica tiene inconvenientes en el contexto Iraní del Inglés como lengua extranjera?}

\author{
Ali Rahimi ${ }^{1}$ \\ Rouhollah Askari Bigdeli ${ }^{2}$
}

Citation / Para citar este artículo: Rahimi, A. \& Askari Bigdeli, R. (2015). Why does critical literacy hit a snag in the Iranian EFL setting? Colomb. Appl. Linguist. J., 17(1), pp. 53-63.

Received: 03-Jul-2014 / Accepted: 18-Dic-2014

DOI: http://dx.doi.org/10.14483/udistrital.jour.calj.2015.1.a04

\begin{abstract}
This study sought to elucidate the challenges of critical literacy practice in the Iranian context. The objectives were twofold: (a) to find out which challenges teachers and students face in the practice of critical literacy and (b) to explore the state of critical literacy in language education. To this end, a sample of 12 English teachers and 120 students majoring in TEFL took part in the study. Data collection procedure was based on students' reflective notes, semi-structured interviews, and classroom observations. The analysis of the interviews revealed that factors including a) lack of the teachers' familiarity with the concept and tenets of critical literacy, b) students' poor English proficiency, c) lack of attention to critical literacy in curriculum and d) political issues were the major challenges. Classroom observations and students' reflective notes showed that teachers did not encourage students to become involved in ideologies imbedded in the texts.
\end{abstract}

Keywords: Critical Literacy, Critical Education, EFL, Literacy

\section{Resumen}

Este estudio trata de dilucidar los desafíos de la práctica crítica de alfabetización en el contexto iraní. Los objetivos fueron dos: (a) averiguar con qué desafíos se enfrentan los profesores y los estudiantes en la práctica de la alfabetización crítica y (b) explorar el estado de la alfabetización crítica en la enseñanza de idiomas. Con este fin, una muestra de 12 profesores de inglés y 120 estudiantes que se especializan en TEFL participó en el estudio. El procedimiento de recolección de datos se basó en las notas de reflexión de los estudiantes, entrevistas semiestructuradas y observaciones en el aula. El análisis de las entrevistas reveló que factores incluyendo a) la falta de familiaridad de los profesores con el concepto y principios de la alfabetización crítica, b) el dominio pobre del inglés de los estudiantes, c) la falta de atención a la alfabetización crítica en el currículo y d) las cuestiones políticas eran los principales retos. Las observaciones en los salones de clase y las notas de reflexión de los estudiantes mostraron que los profesores no animan a sus estudiantes a participar en las ideologías incrustadas en los textos.

Palabras clave: alfabetización crítica, educación crítica, EFL, alfabetización

1 Bangkok University, Bangkok, Thailand. ali.r@bu.ac.th

2 Yasouj University, Yasouj, Iran. raskari90@gmail.com 


\section{Introduction}

\section{Teaching English as a Foreign Language in Iran}

Teaching English as a Foreign Language in Iran has been greatly influenced by conventional teaching methods which focus on memorization of linguistic structures, vocabularies, and inauthentic materials. Mowlaie and Rahimi (2010) found that while Iranian English teachers were acquainted with the tenets and principles of the communicative language teaching method, they did not employ it when it came to practice and preferred the conventional teaching methods in which they as the authorities presented the information and the students passively absorbed it. In the same vein, Rahimi and Chabok (2013) argued that despite the fact that Iranian English teachers emphasized the significance of a learnercentered approach to language teaching, they were somehow willing to be the authority in their classes. It is speculated that this trend of language teaching in Iranian universities is the perpetuation of what Freire (1970) called "banking education" in which the teachers are the possessors of knowledge and the students are considered to be containers or vessels filled by their teachers. Employing and persisting in such approaches to literacy that primarily focus on developing linguistic knowledge and cognitive processes does not lead to higher levels of literacy in language proficiency of Iranian students of English because, as Freebody and Luke (1990) argued, being literate requires more than being able to decode and passively absorb texts. Highlighting the practice of critical literacy in foreign language teaching, Ebrahimi and Rahimi (2013) argued that foreign language learners should not act as transmitters of foreign thoughts and beliefs to their own culture and it is incumbent on them to explore the latent layers of meaning and to perceive the ways in which people try to express their ideologies and thoughts.

\section{Critical Literacy}

According to Shekarey and Rahimi (2006), "critical education is a campaign for removing the suffocating restrictions and boundaries and creating novel situations for 'recycling and reproducing' knowledge" (p. 68). Over the recent years, critical approaches to education and in particular critical literacy have gained a lot of attention (e.g., Beck, 2005; Callison, 2006; Pennycook, 1990, 2001; Shor E Pari, 1999).

Providing a clear-cut definition for critical literacy has proven to be a challenging task and, as pointed out by Green (2001), what constitutes critical literacy differs within the current literature. However, providing a synthesis of literature influenced by the critical literacy definitions as well as by the critical questioning stance toward texts, Lewison, Flint, and Van Sluys (2002) introduced four dimensions of critical literacy including (1) disrupting the commonplace, (2) interrogating multiple viewpoints, (3) focusing on sociopolitical issues, and (4) taking action and promoting social justice. In the first dimension of this framework, critical literacy is conceptualized as seeing the "everyday" through "new lenses." In fact, from this perspective, critical literacy is used to develop the language of critique, to perceive the present knowledge as a historical product, to interrogate texts by asking different questions, to study language in order to support or challenge the status quo, and to understand how cultural discourses are shaped. The focus of the second dimension of the framework is "to understand experience and texts from our own perspectives and the viewpoints of others and to consider these various perspectives concurrently" (Lewison, Flint, E Van Sluys, 2002, p. 383). In fact, open-ended inquires, and multiple and contradictory viewpoints are taken into account and multiple voices are employed to interrogate the texts with the aim of recognizing the voices that have been marginalized. The third dimension posits that critical literacy does not see the act of teaching as neutral practice unaffected by sociopolitical systems and power relationships. Instead, politics of daily life, unequal power relationships, and sociopolitical systems to which students belong are inseparable from the act of teaching (Lewison, Flint, $\mathcal{E}$ Van Sluys, 2002). The fourth dimension tries to depict how readers can achieve social justice by having access to dominant forms of language and culture without devaluing their own language and culture. As a matter of fact, questioning the practices of privilege and injustice, challenging and redefining cultural borders, helping the students to be border 
crossers with the purpose of understanding others and transforming the conditions of injustice and oppression constitute the core of this dimension.

Cadiero-Kaplan (2002) highlighted that it is essential for the teachers not only to be aware of their own ideology toward literacy but also to recognize to what extent the curriculum materials and processes promote literacy. The author argued that critical literacy has been developed to involve the individuals in questioning the historical, political, and social intent of a text. In the same vein, Behrman (2006) argued that examining the power relationships imbedded in language use, realizing that language is not neutral, employing personal values and beliefs in producing and receiving language shape the primary aims of critical literacy education. That is to say, teachers and students work cooperatively to perceive how texts function, what texts intend to communicate, and how social relations can be questioned and reconstructed.

In the realm of English language teaching, Pennycook (2001) employed the concept of critical literacy in order to introduce a new English curriculum in which students must work to construct not only knowledge of text content but also develop knowledge about texts and text genre. In fact, as pointed out by Johnson and Freedman (2005), "when teachers decide to embrace a critical pedagogy, they are deciding to bring a questioning stance into their classroom" (p. 16). McLaughlin and DeVoogd (2004) found that developing and nurturing critical literacy were highly crucial as it benefited students in a number of ways. It enabled the students to read texts in deeper and more meaningful ways to perceive the function and the form of the text, i.e., the motivation the author had for writing a text and the particular way the text was constructed by the author. Also, critical literacy helped the students to be active users of the information in texts in order to develop independent perspectives as contrary to being passive receivers and reproducers of the ideas in texts. In other words, as a product of developing critical literacy, the students could seek and examine absent and silenced perspectives as well as power differences to understand to what extent the status quo or common assumptions and values were maintained or challenged.
There is a dearth of literature on the practice of critical literacy in ESL and EFL classrooms (Ko \& Wang, 2009). In a case study, SoYoung (2011) explored the effectiveness of critical literacy practices with Korean EFL college students. The results evidenced the significant positive correlation between students' use of critical reading and their writing strategies. Also, external factors such as course grades, course requirements, instructors, and group members as well as internal factors such as culturally-mediated expectations, English proficiency, the purpose of learning English, and attitudes toward the critical reading practice were found to be important in promoting students' engagement in the critical reading practice. Furthermore, investigating Taiwanese EFL teachers' perception of the importance of critical literacy in EFL teaching, Ko and Wang (2009) found that the practice of critical literacy in the EFL setting was considered both important and feasible on the part of the teachers. However, the results of the study showed that factors such as students' English proficiency, students' autonomy, teaching resources, cultural difference, and political labeling needed to be taken into account by the teachers when they brought critical literacy into practice. In another study, Falkenstein (2003) found that the practice of critical literacy in the EFL setting encountered a number of obstacles including lack of time on the teacher's behalf, insufficient classroom time, large class size, and cultural expectations of education.

In more recent studies, Janks (2014) argued that teachers should be sufficiently empowered to connect the text they bring to the class to students' daily lives, to encourage students to do the necessary research and help them look for possibilities to make positive differences. Rogers (2014) demonstrated that if teachers are provided with the opportunities to develop and practice critical education, they will have unique and diverging paths in designing critical literacy education. This means that implementing top-down education is at odds with the tenets of practicing critical literacy and that there is need for teachers to be given intellectual freedom to implement critical literacy. Vasquez (2014) stated that "a critical literacy curriculum needs to be lived" (p. 1). It needs to take into account the current social and political conditions with the purpose of 
helping students and teachers understand and act upon those conditions.

In a study that was carried out in Colombia, Mora (2014) introduced graduate students to critical literacy by engaging them in the in-depth analysis of textbooks. The result of the study indicated four issues in the students' analysis: (a) breaking the attachment to the textbooks as a precursor to critical literacy, (b) developing a more critical consciousness, (c) questioning the status quo in the textbooks, and (d) viewing themselves as advocates. Furthermore, investigating an EFL teacher's critical literacy teaching practice in a reading class in Taiwan, Ko (2013) found that the practice of critical literacy not only leads to an increase in students' awareness of ideologies embedded in text, but also helps teachers to abandon the banking model of education and embrace empowering education. The author, however, pointed to the issues including a transmission model of literacy, students' language learning beliefs, and teaching resources as the main challenges for implement critical literacy education. In Ontario, Canada, Lau (2013) developed a critical literacy program base on Cummins' (2001) Academic Expertise Janks' (2010) synthesis model of critical literacy and involved middle school recent immigrant English language learners in an action research study. The result of the study revealed that by providing careful language scaffolding as well as classroom structures and conditions, teachers can involve the students in critical discussions of real concerns. In fact, in an equitable environment, the students can work, formulate, evaluate, and question reading and writing about real-life issues.

Evidence accumulated through such studies corroborate the fact that critical literacy approaches pedagogy in a way that is much needed in today's educational systems across different contexts. Deploying democratic approaches to education that is underscored in many educational contexts depends on the extent to which developing critical literacy is considered and valued by teachers. In fact, the practice of critical literacy invites students to become active agents in education rather than agents that are exploited unconsciously and used as a tool for distribution of power and inequality. As the literature has illustrated, there are a number of obstacles that constrain the practice of critical literacy. The present study was an attempt to investigate the state of critical literacy within the realm of TEFL at Iranian universities. Iranian universities are centralized educational settings in which decisions regarding course aims, objectives, and syllabi are determined and exported to the teachers by higher educational authorities. Teachers have little voice in determining course contents, materials, and assessment policies. Activities regarding significant decision making and leadership policies are strictly under the control of head offices and authorities at the ministry of higher education with little room for local teachers and educators. Centralization of educational policies and planning has rendered teachers and students at the lower level of the educational hierarchy just insignificant cogs in the machinery of focused centralized schooling. The injunctions and commandments issued by the head office are inflexible and stringent and must be categorically followed by disempowered teachers at the bottom rung of the organizational ladder. This rigorous hierarchical arrangement of policy making is entirely different from a decentralized method of exercising a chain of harmonized agents who work in concert to materialize a set of consensual, clear objectives. Much to Iranian teachers' chagrin, the head office of the ministry of higher education makes high stake vital decisions and policies without elicitation of teachers' views and opinions at the relevant local educational settings with respect to the curriculum development, syllabus design, materials developments, evaluation policies, etc.. As a consequence, almost all pedagogical and academic procedures are systematically specified and consistently perpetuated at a centralized location by certain individuals at the top of the organizational structure. These injunctions are indoctrinated, disseminated, and have to be closely practiced by teachers and meticulously followed by students. A decentralized structure formed by a chain of harmonized interrelated agents must replace the current state of affairs. Such a chain of interaction, mediation, feedback, and agreement is the part and parcel of egalitarian transformative democratic education which ensures students' creativity, innovation, and deep levels of thinking. It can also foster students' competency in diverse kinds and levels of literacy, most particularly 
critical literacy. Such a decentralized approach to pedagogy provides teachers and students with the ability to ask intellectually-inspiring questions, and to offer answers with a deeply critical enlightening attitude. They feel that they are empowered and an important part of the pedagogical organism, active and influential members of a symmetrical, fair, and creative system.

As such, we were motivated to explore (a) what challenges Iranian English teachers and students face in the practice of critical literacy and (b) the state of critical literacy in language education in terms of the approaches to teaching English in Iranian universities.

The study sought to answer the following two research questions:

1. What challenges do teachers and students face in the practice of critical literacy in TEFL in Iranian universities?

2. To what extent do the Iranian English teachers' teaching practices promote students' critical literacy?

\section{Methodology}

\section{Participants}

The participants for this study included 12 English teachers ( 7 males and 5 females) and 120 students of TEFL (47 males and 73 females) from two Iranian universities. Of the instructors, 9 were PhD holders in TEFL and 3 had an MA in TEFL. All the teacher participants, with ages ranging from 41 to 47 , had over 6 years of teaching experience at the university level. At the time of the study, the student participants were in their sixth semester completing a BA in TEFL.

\section{Data Collection}

Semi-structured interviews, classroom observations, and students' reflective notes were the main sources of data collection. In order to gather the data to answer the first research question, the semi-structured interviews were conducted with all the teacher participants. It should be pointed out, however, that due to the fact that it was not feasible to include all the student participants in the interviews, 30 students were randomly chosen to be interviewed. The interview questions were structured around the challenges of practicing critical literacy from the perspective of the teachers and the students. All the interviews were taped and transcribed for further analysis.

Classroom observation and students' reflective notes were used to answer the second research question. Observation refers to "the watching of behavioural patterns of people in certain situations to obtain information about the phenomenon of interest" (Johnson \& Christensen, 2004, p. 186). The course that was specified to be observed for the present study was "an introduction to English literature" in which the book titled "Literature: Structure, Sound, and Sense" (Laurence, 1984) was used as the main teaching material. The book is a selection of classic, modern, and contemporary readings and serves to illustrate the elements of literature. Four sessions of two classes taught by two different teachers were observed in order to record the teachers' and students' behaviours with regard to whole-class engagements, activities, tasks, studentteacher and student-student interaction, and discussions. The observed sessions were allocated to a story titled "The Destructors" from "Literature: Structure, Sound, and Sense." In addition, all 120 students taking part in the classes were invited to take reflective notes to describe their impressions and feelings about what was happening in class. In other words, they were invited to take reflective notes of what the perceptions were and how they felt about these. The reflective notes indicated their reaction and feeling about the classroom happenings.

\section{Data analysis}

Data analysis was ongoing throughout the study. The students' reflective notes and the observations were reviewed and analysed as they were collected. The interviews were conducted in English, audio taped, and then transcribed by the researchers. All transcripts were analyzed by means of pattern coding to reduce the "large amounts of data into a smaller 
number of analytic units" (Miles $\&$ Huberman, 1994, p. 69). In the present study, pattern coding was utilized for an accurate interpretation of emergent patterns and themes.

The classroom observations and students' reflective notes were analysed according to a framework developed by Lewison, Flint, and Van Sluys (2002). The four-dimensional model emphasizes readers' critical response to literature as an opportunity for them to be aware of different societal and ideological discourses constructed and conveyed by the literary language. As asserted by Van Sluys, Lewison, and Flint, (2006) "this framework not only helped us better understand critical literacy but also became a useful tool that encouraged teachers to try new critical practices in their classrooms" (p. 198).

\section{Findings}

\section{Challenges to the practice of critical literacy}

The analysis of the interviews with the teachers and the students revealed four major challenges that were thought to be the real deterrents against critical literacy practice within the realm of TEFL in Iranian universities. These challenges include a) a lack of the teachers' familiarity with the concept and tenets of critical literacy, b) the students' poor English proficiency, c) lack of attention to critical literacy in curriculum and d) political issues.

The analysis of the interviews revealed that some of the teachers were not well acquainted with the tenets and features of critical literacy as mentioned above. As one of the teachers, having an MA in TEFL, explicitly stated, "I am familiar with critical literacy but it is not very deep and I am not confident enough how to use it in my teaching." Correspondingly, another MA teacher asserted that "I just read some papers on critical literacy during my MA program a couple of years ago, and now my understanding of critical literacy is vague." Lack of awareness on the part of the teachers in regard to the concept and tenets of critical literacy prevented the students from having the opportunities to explore and construct knowledge. One of the students asserted "we read the texts superficially and focus on the meaning of the content. We hardly ever have discussion on the texts." This lack of awareness made the practice of critical literacy not be considered and valued by the teachers as an essential component of education and accordingly they showed no tendency to practice critical literacy. As one of the PhD-holding teachers stated "... critical literacy can be developed by self-study and time of class is too limited to be devoted to critical literacy." This shows that learning environment and teaching techniques and strategies affect the development of critical literacy skills and strategies to a great extent.

The second reason as pointed out by the teachers was the English students' poor proficiency. Most of the teachers believed that understanding texts critically required a high level of English proficiency not already developed by their students. Despite the fact that some of the teachers underscored critical literacy practice and believed that in today's world the students should be prepared to have critical perspectives, they asserted that with limited English proficiency the practice of critical literacy languished. One of the teachers stated "When students cannot express themselves well in English it is too hard to think of critical questions. To address a text critically, in fact, more complex understandings of the texts are needed." In fact, the low level of proficiency made the teachers disregard critical literacy practice. A teacher teaching "an introduction to literature" course mentioned that "when I want to teach literature, I find that my students should learn English first. I mean, much time of class is spent on learning language rather than literature and it is obvious that critical literacy cannot be practiced in this situation." However, one of the teachers believed that students' proficiency level cannot be a serious deterrent against the practice of critical literacy if the teachers can adeptly ask a variety of questions. She believed that "it is the ability to ask a variety of questions that can foster critical literacy practice not the students' proficiency level."

Lack of attention to critical literacy in the curriculum was the third reason that prevented 
Why does critical literacy hit a snag in the Iranian EFL setting?

critical literacy from being properly practiced. Teachers stated that the practice of critical literacy was not formally approved by the TEFL curriculum in the country and this resulted in a shortage of teaching materials developed to promote students' critical literacy. One of the teachers asserted that "critical literacy is silent in the curriculum." For the same reason, the teachers did not position the practice of critical literacy in the daily enactment of subject-area curriculum. Another teacher, holding a $\mathrm{PhD}$, asserted that "there is no such a thing as critical literacy practice in the curriculum. And like other teachers I have to stick to the course objectives stated in the syllabus." This fact was further corroborated by the students who pointed out that critical literacy practice was not part of the objectives of the courses included in the syllabus. In other words, critical literacy practice was silent in the syllabus developed for students doing their TEFL at Iranian universities. This shows that teachers were constrained by the curriculum that was exported to their classrooms. In fact, the teachers might not be free to exercise their professional decisions. In this regard, teachers are viewed as "technicians carrying out instruction determined by someone else" (Wien $\mathcal{E}$ DudleyMarling, 1998, p. 410).

The last reason emerging through the analysis of the interviews with the teachers and the students was the political issues that were thought to be the deterrent against the practice of critical literacy. It appears that discussing political issues in class with the aim of enhancing the students' critical literacy was not welcomed by both the teachers and the students. It is because critical literacy challenges the perpetuated status quo and invites the readers to enter into dialogues to question unequal power relationship by studying the relationship between language and power. One of the teachers stated that:

Examining the political assumptions that underlie the texts and discussing them with the students are a bit disturbing for me because talking politically is a sensitive issue and needs to be treated with lots of care and attention. Albeit necessary, many teachers overlook this issue in their teaching.
One of the students asserted that:

When we start talking about political topics that are related to our lesson or our course, our teachers prefer to end the conversation as soon as possible or divert our attention away from politics by changing the line of discussion.

As far as the results of the present study are concerned, the conventional learning environment at Iranian universities cannot be conducive to effective critical literacy which necessitates vivacious involvement in socio-political ideological issues dominant in society. What's more, this traditional education context does not offer the learners the chance to practically engage in genuine authentic academic activities demanding a range of psychological and social snippets of information. In such a traditional teaching approach, the teacher is the controller of the learning environment. Power and responsibility are held by the teacher who plays the role of instructor in the form of lectures and decision makers in regards to curriculum content and specific outcomes. This confinement of intellectual activities to the classroom is blatantly pandemic in Iranian educational settings due to the perpetuation of the old traditional pedagogical practices.

The bottom line is that materials, textbooks, curricula, and syllabi ratified by higher education in Iran do not encourage discussions outside the physical boundaries of the class thus blocking student's change from inactive recipients of information to critical innovate readers, writers, and critical thinkers ultimately. These classroom environments turn out to be repressing and suffocating rather than educationally enlivening and invigorating. It may be pointed out that while working in a situation stimulating critical literacy, students can, even at a low level of proficiency, spot their problems and not brush them under the carpet. They can specify the roots of problematic areas through the development of their deep thinking, innovation, and creativity skills.

\section{The state of critical literacy}

The second research question was concerned with the extent to which critical literacy was practiced 
in terms of the teaching practices used in English classes. The four-dimensional framework developed by Lewison, Flint, and Van Sluys (2002) was used as the framework to analyze the data.

\section{Disrupting the commonplace}

The sessions observed were devoted to a story titled "The Destructors" from "Literature: Structure, Sound, and Sense" (Laurence, 1984). The story is ironic and depicts how destruction is a form of creation. The major events of the story were about a gang, composed of a group of boys, who planned to demolish a beautiful two hundred-year-old house owned by Mr. Thomas whom the gang called "Old Misery."

During the session, to challenge the students' "common knowledge," a number of questions were raised by the teachers including "Do you think the act of the gangs is a sample of creation or vandalism from the perspective of cultural frames?", "Do we readers do with Mr. Thomas the same the gang did?", "How are their deeds perceived in our society?", "Is destruction inherent in nature of human kind?" The questions led to an exchange of talk and discussion between the teacher and the students.

The dimension of "DisruptingtheCommonplace" emerged in some ways in the classes. The teachers challenged the students to think critically and provided them with the circumstances which could challenge their commonly established beliefs and assumptions.

\section{Interrogating multiple viewpoints}

Despite the fact that "The Destructors" had the capacity to provide its readers with different and contradictory perspectives, interrogating multiple viewpoints was not significantly addressed. "The Destructors" tells the story of a gang of kids who plan to destroy an old man's house. This is a bit bizarre because tearing down the others' houses is not something the kids would spend their free time doing, and the author might intend to create these characters symbolic of particular people in society. These contradictions as well as authorial choices regarding the characters and the situation could lend themselves to discussions about various perspectives and viewpoints. In general, the author presented the meaning of the story through several binary oppositions including young age versus old age, war versus peace, and destruction versus construction which could all lend themselves the discussion of different viewpoints. Questions such as "What if the kids were adults?" or "Do age and gender have anything to do with the crime the kids committed?" were neither raised by the teacher nor asked by the students.

\section{Focusing on socio-political issues}

In "The Destructors," Blackie, the leader of the gang, claimed that he had seen the last bomb of the Blitz. The Blitz referred to the eight-month-long bombing of Britain by Nazi Germany in World War II. The kids, the characters of the story, were too young to understand the war, but they were growing up in a state of disarray and chaos in their country. In light of these events in the story, it was expected that the teachers and the students entered into a dialogue to discuss factors such as rates of homelessness, poverty, death, segregation, and destruction that are related to incidents brought about by war. Social, psychological, economic, and environmental effects of war on different generations including kids, the characters of "The Destructors," were not brought up by the teachers.

\section{Taking action and promoting social justice}

In "The Destructors," questions such as "What are the dominant beliefs about using war as an oppressive tool?" and "What are the repercussions of war on children?" were expected to be asked. Students could have been asked to go to the Internet in order to find information about these questions.

Pooling together, except for the first dimension in which the idiosyncratic aspect of reading in the form of text-to-self connections emerged, in other dimensions the teachers did not help nor encourage the students to become active and engaged readers to be able to seek meaning and question the ideologies imbedded within the texts they read. That is to say, students were not provided with opportunities to experience the literary texts actively 
and to go beyond personal experience to relate the text to social, historical, cultural, and political aspects of world; rather a large proportion of class time was spent on information about what the text meant. As far as the findings of the present study are concerned, skills and strategies the students need to develop a critical attitude towards the texts and the world cannot be acquired through the approaches in which instructors are viewed as those possessing and transmitting knowledge to the passive and silent students whose job is only to receive and accumulate information.

\section{Discussion and conclusion}

Despite the fact that critical literacy can prepare the students to examine and view the world from a number of different perspectives as well as enable them to understand the sociopolitical systems and the relationships between power and language, Iranian English teachers teaching at the university level did not involve critical literacy in their teaching practices. In fact, the teachers' plans, goals, and expectations for discussions were not in line with the goals and the tenets of critical literacy. They intended to view teaching and learning English as a new way of communication without political, social, and critical significance (Akbari, 2008). In this regard, the findings of the present study corroborated the findings of other researchers (e.g., Braxley, 2008; Crookes \& Lehner, 1998; Pennycook, 1990) who held that apolitical, linguistic, and neutral perspectives on language teaching continue to have perpetuated through the realm of English language teaching. It appears that the discourse in ELT that regards teaching and internalization of English as natural and neutral (Pennycook, 1994) is still perpetuated within the realm of TEFL in Iranian universities. In addition, the findings of the study are in line with the argumentation put forth by Akbari (2008) that:

Implementation of a critical model in any local context has a number, among which decentralization of decision making (in terms of content, teaching methodology, and testing) is of crucial importance. As long as course contents and testing methods are decided upon by ministers in capital, ELT classes suffer from vague generalities and socio-political numbness. (p. 282)

Thus, there is a need for a transformation of teaching and learning English in Iranian universities from a neutral position to one that involves critical pedagogy in which students are regarded as active agents. As Stevens and Bean ( 2007) mentioned, it is not sufficient and fruitful for the students to merely engage in reading texts. Instead, they must have the opportunities to deconstruct information inside and outside of the classroom. As far as the results of the present study are concerned, the teachers need to prepare the students for higher levels of critical literacy helping them go beyond shallow memorization of data to acquire logical reasoning and critical thinking skills.

As a point of caution, teachers must be warned against the traditional role of teacher which is a recipe for an undesirable educational outcome. The teacher adopting a "tap water" approach to teaching impedes students' deep thinking through tedious uninspiring tasks and routines. The teacher's role in a critical literacy classroom is mainly that of mentor and facilitator or mediator to stimulate students' initiative in expressing their free opinions on sociopolitically dominant issues. Such a teaching method encourages the students to interpret and evaluate realities and phenomena in a profound manner away from any bias, cliché, or hackneyed threadbare argumentations. In what follows, a number of recommendations are proposed as a response to the formidable problem of critical literacy practice within the realm of TEFL in Iranian settings.

\section{Recommendations}

Comber (2001) suggests that "critical literacy needs to be continually redefined in practice" (p. 100). Luke (2000) argued against a "formula for 'doing' critical literacy in the classroom" (p. 453), advocating an organic approach to critical literacy in which teachers and students "invent" critical literacies in the contexts of the classroom. 
McLaughlin and DeVoogd (2004) warned that critical literacy strategies are dynamic and must be adapted to the contexts in which they are used and cannot be overgeneralized from one class to another. However, in light of the findings obtained from the present study, the ensuing recommendations in regard to the practice of critical literacy within the realm of TEFL at Iranian universities are proposed.

As far as the findings of the present study are concerned, the teachers' awareness of the concept of critical literacy was among the challenges which prevented critical literacy from being effectively practiced. Also, lack of attention to critical literacy in curriculum as well as teaching resources was found to be working against the practice of critical literacy. Hence, it appears that there is a need for both the teachers and the students to be well acquainted with the principles, tenets, and theories of critical literacy particularly in the first years of their study at the university level. Specifying introductory courses in critical literacy in the syllabus will help the students to become active respondents to certain critical issues discussed in the texts. In such a course, the principles of critical discourse analysis can be introduced to the students. In an empirical study, KoupaeeDar, Shams, and Rahimi (2010) found that different techniques of critical discourse analysis can be used to enhance EFL students' abilities in revealing the hidden layers of meaning implied in the texts.

In addition, there is a need to change and reform the current teaching methodologies that Iranian English teachers employ at universities where the students have been considered as the passive participants and the transmission model of instruction has been dominant. In other words, through the combination of "language of critic" and "language of possibility" (Shekarey \& Rahimi, 2006), the teachers should put the principles of critical education into practice giving students the opportunities to develop and enhance their critical literacy, find their voice, and to understand "political meaning" of education (Popkewitz, 1988).

\section{References}

Akbari, R. (2008). Transforming lives: Introducing critical pedagogy in ELT classrooms. ELT Journal, 62, 276283.

Beck, A. S. (2005). A place for critical literacy. Journal of Adolescent $\mathcal{E}$ Adult Literacy, 48(5), 392-400.

Behrman, E. H. (2006). Teaching about language, power, and text: A review of classroom practices that support critical literacy. Journal of Adolescent $\&$ Adult Literacy, 49(6), 490-498.

Braxley, K. (2008). Mastering academic English: international graduate students' use of dialog and speech genres to meet the writing demands of graduate school. In J. K. Hall, G. Vitanova, \& L. Marchenkova (Eds), Dialog with Bakhtin on second and foreign language learning: New perspectives (pp. 10-28). Mahwah, NJ and London: Lawrence Erlbaum Associates.

Cadiero-Kaplan, K. (2002). Literacy ideologies: Critically engaging the language arts curriculum. Language Arts, 79(5), 372-381.

Callison, D. (2006). Critical literacy and inquiry. Educators ‘ Spotlight Digest, 1(3). Retrieved from http://www. informationliteracy.org/users_data/admin/Volume1 Issue3_Guest_writer.pdf

Comber, B. (2001). Critical literacies and local action: Teacher knowledge and a "new" research agenda. In B. Comber E A. Simpson (Eds.), Negotiating critical literacies in classrooms (pp. 271-282). Mahwah, NJ: Earlbaum.

Crookes, G., E Lehner, A. (1998). Aspects of process in an ESL critical pedagogy teacher education course. TESOL Quarterly, 32(2), 319- 328.

Cummins, J. (2001). Negotiating identities: Education for empowerment in a diverse society (2nd ed.). Los Angeles, CA: CABE.

Ebrahimi, N. A., \& Rahimi, A. (2013). Towards a more efficient EFL reading comprehension classroom environment: The role of content and critical reading. Apples-Journal of Applied Language Studies, 7(2), $1-15$.

Falkenstein, A. (2003). Critical literacy in an EFL context (Unpublished doctoral dissertation). Indiana University, United States.

Freebody, P., \& Luke, A. (1990). Literacies programs: Debates and demands in cultural context. Prospect: Australian Journal of TESOL 5(7), 7-16. 
Why does critical literacy hit a snag in the Iranian EFL setting?

Freire, P. (1970). Pedagogy of the oppressed. New York: Continuum.

Green, P. (2001). Critical literacy revisited. In H. Fehring \& P. Green (Eds.), Critical literacy: A collection of articles from the Australian Literacy Educators' Association (pp. 7-13). Newark, Delaware: International Reading Association.

Janks, H. (2010). Literacy and power. New York, NY: Taylor E Francis.

Janks, H. (2014). Critical literacy's ongoing importance for education. Journal of Adolescent E Adult Literacy, 57(5), 349-356.

Johnson, B., \& Christensen, L. (2004). Educational research: Quantitative, qualitative, and mixed approaches. Boston: Pearson/Allyn and Bacon.

Johnson, H., \& Freedman, L. (2005). Developing critical awareness at the middle level: Using texts as tools for critique and pleasure. Newark, DE: International Reading Association.

Ko, M. Y. (2013). A case study of an EFL teacher's critical literacy teaching in a reading class in Taiwan. Language Teaching Research, 17(1), 91-108.

Ko, M. Y., \& Wang, T. F. (2009). Introducing critical literacy to EFL teaching: Three Taiwanese college teachers' conceptualization. Asian EFL Journal, 11(1), 174-191.

KoupaeeDar, Z., Rahimi, A., \& Shams, M. (2011). Teaching reading with a critical attitude: Using critical discourse analysis (CDA) to raise EFL university students“ critical language awareness (CLA). International Journal of Criminology and Sociological Theory, 3(2), 457-476.

Lau, S. M. C. (2013). A study of critical literacy work with beginning English language learners: An integrated approach. Critical Inquiry in Language Studies, 10(1), 1-30.

Laurence, P. (1984). Literature: Structure, sound, and sense. America: Harcourt Brace Jovanovich.

Lewison, M., Flint, A. S., \& Van Sluys, K. (2002). Taking on critical literacy: The journey of newcomers and novices. Language Arts, 382-392.

Luke, A. (2000). Critical literacy in Australia. Journal of Adolescent E Adult Literacy, 43(5), 448-461.

McLaughlin, M., \& DeVoogd, G. (2004). Critical literacy as comprehension: Expanding reader response. Journal of Adolescent $\mathcal{E}$ Adult Literacy, 48(1), 52-62.

Miles, M. B., \& Huberman, A. M. (1994). Qualitative data analysis: An expanded sourcebook. Sage publications.
Mora, R. A. (2014). Critical literacy as policy and advocacy. Journal of Adolescent \& Adult Literacy, 58(1), 16-18.

Mowlaie, B., \& Rahimi, A. (2010). The effect of teachers' attitude about communicative language teaching on their practice: Do they practice what they preach? Procedia-Social and Behavioral Sciences, 9, 15241528.

Pennycook, A. (1990). Critical pedagogy and second language education. System, 18(3), 303-314.

Pennycook, A. (1994). The cultural politics of English as in international language. Longman: Routledge.

Pennycook, A. (2001). Critical applied linguistics: A critical introduction. London: Routledge.

Popkewitz, T. (1988). Culture, pedagogy and power: Issues in the production of values and colonialization. Journal of Education, 170(2), 77-90.

Rahimi, A., \& Chabok, S. (2013). EFL teachers' levels of reflective teaching and their conceptions of teaching and learning. Journal of Advanced Social Research, 3(1), 12-29.

Rogers, R. (2014). Coaching literacy teachers as they design critical literacy practices. Reading $\&$ Writing Quarterly, 30(3), 241-261.

Shekarey, A., \& Rahimi, A. (2006). The consequences of binary opposition/ continuation approaches to modernism and postmodernism: A critical educational study. TAMARA Journal for Critical Organization Inquiry, 1(5), 63-71.

Shor, I. \& Pari, C. (1999). Critical literacy in action: Writing words, changing worlds. Boynton: Cook Publishers.

SoYoung, Y. (2011). Critical literacy practices in a Korean EFL context: A case study of Korean undergraduates learning English reading and writing (Unpublished doctoral dissertation). Indiana University, United States.

Stevens, L. P., \& Bean, T. W. (2007). Critical literacy: Context, research, and practice in the K-12 classroom. New York: Sage.

Van Sluys, K., Lewison, M., \& Flint, A. S. (2006). Researching critical literacy: A critical study of analysis of classroom discourse. Journal of Literacy Research, 38(2), 197-233.

Vasquez, V. M. (2014). Negotiating critical literacies with young children. Routledge: New York.

Wien, C. A., \& Dudley-Marling, C. (1998). Limited vision: The Ontario curriculum and outcomes-based learning. Canadian Journal of Education, 23(4), 405-420. 